| Modal Sosial dalam Strategi Industri Kecil

\title{
MODAL SOSIAL DALAM STRATEGI INDUSTRI KECIL
}

\author{
Eni Fitriawati ${ }^{1}$
}

\begin{abstract}
Abstrak
Dewasa ini banyak bermunculan sektor perindustrian baik dalam lingkup industri kecil maupun industri rumah tangga, mulai dari industri pangan maupun industri kreatif. Industri kecil slondok merupakan industri kecil yang berkembang di Desa Sumurarum yang dikerjakan secara turuntemurun dan terus berkembang sampai sekarang. Pada tahun 1973 industri kecil slondok hanya dilakukan oleh bapak Bajuri dan dikerjakan secara manual. Seiring berkembangnya teknologi maka sekarang pengerjaan dengan menggunakan mesin dan industri kecil slondok kini berkembang menjadi sentra industri kecil di kota Magelang. Penelitian ini bertujuan mendeskripsikan profil industri kecil slondok, mulai dari sejarah, komponen industri (pengrajin, penadah, pemasok, buruh, bahan baku, teknologi ), dan mendeskripsikan bagaimana modal sosial dalam strategi industri kecil slondok di Desa Sumurarum, Kecamatan Grabag, Kabupaten Magelang.

Penelitian menggunakan metode penelitian kualitatif. Sumber data dalam penelitian ini adalah melalui sumber data primer yang diperoleh melalui teknik wawancara mendalam (in-depth interview) dengan pengrajin, penadah, dan pemasok bahan baku dalam industri kecil slondok di Desa Sumurarum. Subjek penelitian adalah pengrajin slondok di Desa Sumurarum. Untuk sumber data sekunder diperoleh melalui studi kepustakaan seperti monografi desa, dan handout pengolahan makanan dalam cluster industry slondok/puyur di Desa Sumurarum, dan foto atau gambar. Teknik pengambilan sampel itu menggunakan cara Purposive Sampling, sedangkan untuk mengabsahkan data menggunakan teknik triangulasi. Dalam memeriksa keabsahan data ini peneliti menggunakan triangulasi sumber. Analisis data ini menggunakan Model Analisis Interaktif dari Milles dan Hubberman.

Hasil penelitian ini menunjukan bahwa: 1) Industri kecil slondok yang terdapat di Desa Sumurarum, Kecamatan Grabag, Kabupaten Magelang merupakan industri kecil yang berkembang mulai dari satu unit industri dan kini menjadi sentra industri kecil, 2) Modal sosial berperan sangat penting dalam strategi industri kecil slondok. Kepercayaan mempunyai peran penting dalam proses produksi, norma atau aturan mempunyai peran penting dalam pembentukan harga bahan baku dan harga slondok tawar serta dalam kesepakatan kerja. Jaringan mempunyai peran penting dalam jalinan usaha untuk pemasaran hasil industri kecil slondok. Modal sosial mempunyai peran
\end{abstract}

\footnotetext{
${ }^{1}$ Penulis adalah alumni Program Studi Pendidikan Sosiologi, FISE, Universitas Negeri Yogyakarta
} 
sebagai strategi dalam pengembangan industri kecil slondok khususnya bagi pengrajin .

Kata kunci: strategi, industri kecil slondok, peran.

\section{A. Pendahuluan}

Industri merupakan kegiatan ekonomi yang mengolah bahan mentah menjadi barang jadi atau barang setengah jadi. Dalam lingkup perindustrian terdapat berbagai skala yakni industri kecil, sedang, besar, dan industri rumah tangga. Industri kecil selalu ditu njuk sebagai sektor kunci dalam penciptaan lapangan kerja. Efek kesempatan kerja yang diciptakan oleh industri kecil akan lebih besar dari pada efek serupa yang dihasilkan oleh industri besar. Selain itu, dari penyebaran dan keterkaitan yang erat dengan se ktor pertanian, industri kecil sangat potensial untuk mendorong perekonomian pedesaan. $^{2}$

Industri kecil slondok sebagai industri makanan yang berbahan baku ketela pohon mempunyai nilai jual yang cukup tinggi. Industri kecil slondok merupakan industri kecil dikerjakan secara turuntemurun dengan bahan baku dari daerah setempat. Dahulu, ketela pohon diolah menjadi rengginan, samier, ceriping dan tape. Setelah itu produksinya mengalami peningkatan, yaitu ketela pohon diolah menjadi slondok dan kemudian berkembang pada masyarakat sekitar sampai dengan sekarang.

\footnotetext{
Hendrawan Supratikno, Perkembangan Industri Kecil di Indonesia, majalah PRISMA, No 9, 1994. Hlm. 26
}

Awalnya sekitar tahun 1973 industri kecil slondok hanya dilakukan oleh bapak Bajuri (pioner industri kecil slondok di Dusun Purwogondo Desa Sumurarum) yang dikerjakan menggunakan mesin manual. Kemudian pada tahun 1984 seiring dengan masuknya listrik di Desa Sumurarum bapak Bajuri mulai merancang dan membuat mesin yang dapat digunakan sebagai alat dalam proses produksi dalam industri kecil slondok .

Baru beberapa saat kemudian ketika pemasaran hasil industri kecil slondok semakin meningkat dan semakin terasa fungsi ekonominya maka tetanggatetangga bapak Bajuri (yang juga merupakan karyawan bapak Bajuri) diantaranya mulai ikut memproduksi slondok, dan kemudian berkembang juga pada Dusun-dusun di Desa Sumurarum, diantaranya Dusun Karang, Dusun Semarum dan Dusun Maggung. Bahkan sekarang masyarakat pada Desa Sumurarum menggantungkan penghasilannya pada industri kecil slondok.

Sentra industri kecil slondok ini banyak tersebar di Kabupaten Magelang, tepatnya di Desa Sumurarum Kecamatan Grabag. Selain sebagai petani sebagian besar mata pencaharian masyarakat Desa Sumurarum adalah sebagai pengrajin slondok (pemilik industri kecil slondok). Desa ini menjadi 
sentra industri kecil slondok karena jumlah pengrajin slondok yang cukup banyak serta menjadinya slondok sebagai produk unggulan di Kabupaten Magelang yang selalu mewakili Kabupaten Magelang dalam Jakarta Fair.

Dengan menjadinya desa ini sebagai sentra industri kecil slondok maka semua itu tidak terlepas dari komponen-komponen industri yang ada (pemasok, pengrajin, pembumbu dan buruh). Jika hanya melihat sepintas saja hasil industri ini tentu tidak dibayangkan bahwa untuk menghasilkan produk tersebut tidaklah mudah. Untuk menghasilkan slondok tersebut harus melewati beberapa proses dan dalam beberapa proses tersebut menyerap beberapa komponen produksi. Komponen-komponen tersebut kemudian membentuk suatu relasi yang mulai dari pemasok bahan baku, pengrajin, pembumbu dan para buruh.

Dari beberapa komponen industri mulai dari pemasok bahan baku, pengrajin, pembumbu, dan buruh tidak dapat dipisahkan satu dengan yang lainnya, karena semua memiliki hubungan yang saling mendukung. Produksi slondok ini memang harus melewati beberapa proses produksi dan dalam proses tersebut dilakukan oleh komponenkomponen industri. Maka pengrajin tidak akan menghasilkan slondok sendiri tanpa adanya bantuan dari komponen industri lain yaitu pemasok bahan baku dan para buruh.
Secara

historis

perkembangan industri kecil slondok yang dimulai dari satu unit industri hingga kini Desa Sumurarum dikenal sebagai sentra industri kecil slondok. Tidak terlepas dari adanya strategi pengembangan yang meliputi proses produksi, pemasaran, dan pembentukan harga. Pembentukan harga bahan baku, segar putihan, dan harga slondok siap distribusi yang didalamnya terdapat jaringan, kepercayaan serta norma sebagai pengendali strategi dalam pengembangan industri tersebut. Modal sosial dalam strategi industri disini lebih memfokuskan pada peran modal sosial dalam stra tegi industri kecil yang mengkaji industri kecil slondok (proses produksi, pemasaran, dan pembentukan harga).

Tujuan penelitian ini adalah: 1) untuk mengetahui profil industri kecil slondok sebagai home industry yang berkembang pada masyarakat di Desa Sumurarum, 2) mendeskripsikan bagaimana modal sosial dapat berperan dalam strategi pengembangan industri kecil slondok di Desa Sumurarum.

\section{B. Kajian Pustaka}

\section{Industri}

Pengertian industri dalam Kamus Besar Bahasa Indonesia diartikan sebagai kegiatan memproses atau mengolah barang dengan menggunakan sarana dan 
peralatan. ${ }^{3}$ Industri kecil di Singapura didefinisikan sebagai unit usaha industri yang mempekerjakan antara 10 sampai 99 orang tenaga kerja, di Malaysia dan Muangthai industri didefinisikan sebagai unit usaha yang mempekerjakan tidak lebih dari 50 orang tenaga kerja. Sementara di Indonesia serta Filipina didefinisikan sebagai unit usaha industri yang mempekerjakan antara 5 sampai 19 orang tenaga kerja. ${ }^{4}$

Agus Dwiyanto menyatakan bahwa industri kecil dan rumah tangga merupakan usaha dalam skala kecil yang dilakukan oleh anggota keluarga dengan teknologi yang relatif sederhana. Sebagian besar industri jenis ini tidak menuntut keahlian yang tinggi dari pekerjanya dan biasanya berada di daerah pedesaan. Secara umum industri kecil mempunyai karakteristik antara lain menyerap tenaga kerja besar, berada di pedesaan, modal kecil, teknologi tradisional, tenaga kerja keluarga, bahan baku lokal, berhubungan dengan pertanian dan pasar lokal. ${ }^{5}$

Industri kecil yang sebagian besar berada di daerah pedesaan memegang peranan penting bagi pembangunan ekonomi di pedesaan dan usaha pemerataan. Hal tersebut terjadi karena:

a. Industri kecil memberikan lapangan kerja pada

\footnotetext{
3 Depdiknas, Kamus Besar Bahasa Indonesia, Jakarta: Balai Pustaka, 2005. hlm.337.

${ }^{4}$ Irsan Azhary Saleh, Industri Kecil (Sebuah Tinjauan dan Perbandingan). 1986, hlm. 4.

5 Agus Dwiyanto, Manusia dan Pembangunan, Jakarta: Rajawali, 1996, hlm.300.
}

penduduk pedesaan yang pada umumnya tidak bekerja secara utuh.

b. Industri kecil memberikan tambahan pendapatan tidak saja bagi pekerja atau kepala keluarga, tapi bagi anggota keluarga lain.

c. Dalam beberapa hal industri kecil mampu memproduksi barang - barang keperluan penduduk setempat dan daerah secara lebih efisien atau lebih murah dibandingkan in dustri besar menengah. ${ }^{6}$

Industri kecil slondok adalah sektor industri kecil menengah yang mengelola ketela pohong menjadi slondok. Sesuai dengan yang dikemukakan oleh Agus Dwiyanto dalam kutipan di atas, dimana industri kecil rumah tangga merupakan sektor industri dalam skala kecil yang dilakukan oleh anggota keluarga dengan teknologi yang relatif sederhana dalam industri kecil slondok tersebut sebagian besar tenaga kerja adalah anggota keluarga, dengan menggunakan mesin-mesin yang sederhana seperti halnya parut dengan menggunakan dinamo dan mesin penggiling.

\section{Modal Sosial}

Modal sosial dapat diterapkan untuk berbagai kebutuhan, namun yang paling banyak adalah untuk upaya pemberdayaan masyarakat. Modal

\footnotetext{
${ }^{6}$ Mubyarto, Politik Pertanian dan

Pembangunan Desa. Jakarta: Sinar Harapan. 1983, hlm.261.
} 
sosial adalah satu faktor penting yang menentukan pertumbuhan ekonomi masyarakat. Tanpa adanya kerukunan dan kerjasama yang sinergi akan semakin sulit berkembangnya ekonomi masyarakat. Seperti halnya pendapat Boourdeou yang menyatakan bahwa modal ekonomi bukanlah modal dari segala modal. ${ }^{7}$

Robert D. Putnam, ilmuwan politik yang berasal dari Amerika telah memperoleh banyak penghargaan karena mempopulerkan modal sosial yang sebelumnya merupakan suatu terminologi yang agak kabur, dengan menyelamatkannya dari abstraksi sosial dan teori ekonomi. Definisi Putman pada tahun 1996 tentang modal sosial menyatakan bahwa "corak-corak organisasi sosial, seperti kepercayaan, norma, dan jaringan yang menyanggupkan para partisipan untuk bertindak bersama lebih efektif untuk mengejar tujuan-tujuan bersama". 8 Modal sosial inheren dalam struktur relasi antar individu. Struktur relasi dan jaringan inilah yang menciptakan berbagai ragam kewajiban sosial, menciptakan iklim saling percaya, membawa saluran informasi, dan menetapkan normanorma dan sanksi sosial bagi para anggotanya. ${ }^{9}$ Coleman menyatakan bahwa terdapat tiga bentuk modal

\footnotetext{
${ }^{7}$ John Field, Modal Sosial. Medan: Bina Media Perintis, 2005, hlm.21.

${ }^{8}$ Ibid, hlm. 45 .

9 Jausairi Hasbullah, Social Capital (Menuju Keunggulan Budaya Manusia Indonesia), Jakarta: MR-United Pres, 2006, hlm.7.
}

sosial pertama, kewajiban, dan harapan yang ditentukan atas tingkat kepercayaan yang ada dalam sebuah lingkungan sosial. Kedua, potensi informasi untuk mampu mengalir dalam struktur sosial sehingga dapat dijadikan dasar untuk bergerak. Dan yang ketiga, adanya norma yang dilengkapi dengan sanksi yang efektif. ${ }^{10}$

Modal sosial berperan sebagai perekat yang mengikat semua orang dalam masyarakat untuk mengakses sumber-sumber keuangan, mendapatkan informasi, menemukan pekerjaan, merintis usaha, dan meminimalkan biaya transaksi. Demikian juga yang sering dilakukan para pemilik industri kecil slondok memanfaatkan modal sosial untuk mengakses sumber-sumber keuangan, mendapatkan informasi, merintis industri dengan menggunakan bentuk-bentuk dari modal sosial yaitu: memiliki dan menjaga kepercayaan, menjalin hubungan baik untuk membentuk jaringan dan menjaganya dengan norma -norma yang telah disepakati bersama. Dan mungkin hal yang sama juga dilakukan oleh para pelaku industri kecil slondok di Desa Sumurarum.

a. Kepercayaan (Trust)

Kepercayaan ibarat pelumas yang membuat jalannya kelompok atau organisasi menjadi lebih

${ }^{10} \mathrm{Ibid}$, hlm. 34-39. 
efisien. ${ }^{11}$ Kepercayaan adalah efek samping yang sangat penting dari norma-norma sosial kooperatif yang memunculkan social capital. ${ }^{12}$ Kepercayaan bukanlah merupakan barang baku (tidak berubah), tetapi sebaliknya ia terus-menerus ditafsirkan dan dinilai oleh para aktor yang terlibat dalam hubungan perilaku ekonomi. ${ }^{13}$ Kepercayaan memberikan banyak akses pada berbagai sumber daya, suatu jaringan kepercayaan yang tinggi akan berfungsi lebih lancar dan lebih mudah daripada kepercayaan yang rendah.

Pada mulanya mungkin pemilik industri tidak bisa dengan mudah meminjam uang kepada penadah untuk dijadikan modal misalnya, begitu juga dengan para penadah pada awalnya mungkin tidak diberi kesempatan untuk kredit/ tenggang waktu pelunasan, tetapi setelah semakin lama berh ubungan mereka saling kenal secara mendalam bisa menimbulkan sebuah rasa saling percaya antara pemilik industri dan penadah. Yakni melekat konsep kepercayaan (trust) dalam relasi industri di Desa Sumurarum.

b. Jaringan Sosial (Sosial Network)

Definisi jaringan yang ada pada umumnya digunakan oleh para sosiolog sangat luas dan mencakup pasar maupun hierarki sebagaimana dipahami oleh para

11 Francis Fukuyama, The Great Disruption (Hakikat Manusia dan Rekonstruksi Tatanan Sosial). Jakarta: Qalam, 2007, hlm. 22.

${ }^{12}$ Ibid. hlm. 72.

${ }^{13}$ Damsar, Sosiologi Ekonomi. Jakarta: Raja Grafindo Persada, 1997, hlm. 42. ekonom. Jaringan didefinisikan organisasi formal dimana tidak ada sumber formal dari otoritas yang berdaulat, sementara yang lain memahami sebagai serangkaian hubungan atau aliansi informal diantara berbagai organisasi, yang masing -masing mungkin bersifat hierarkis tapi berhubungan satu dengan yang lain melalui hubungan-hubungan kontraktual vertikal. Jika memahami jaringan bukan sebagai tipe organisasi formal, tetapi sebagai modal sosial akan mendapat wawasan yang lebih baik mengenai fungsi ekonomi jaringan tersebut. Dengan pandangan ini, jaringan merupakan hubungan moral kepercayaan. Jaringan diartikan sebagai sekelompok agen-agen individual ${ }^{14}$ yang melampaui nilai -nilai atau norma-norma dalam jaringan usaha. Selanjutnya jaringan usaha yang berbasis pada aktivitas ekonomi, Granoveter menjelaskan adanya keterlekatan perilaku ekonomi dalam hubungan sosial dengan melalui jaringan sosial yang terjadi dalam kehidupan ekonomi. Pada tingkatan antar individu, jaringan sosial dapat diartikan sebagai rangkaian hubungan yang khas di antara sejumlah orang dengan sifat tambahan, yang ciri ciri dari hubungan ini sebagai keseluruhan, yang digunakan untuk menginterpretasikan tingkah laku sosial dari individu -individu yang terlibat. ${ }^{15}$ Jaringan telah lama dilihat sebagai suatu hal yang sangat penting dalam keberhasilan bisnis.

\footnotetext{
${ }^{14}$ Fukuyama. op.cit. hlm.324.

${ }^{15}$ Damsar. op.cit. hlm. 43-44.
} 
Fungsi jaringan -jaringan diterima sebagai suatu sumber informasi penting, yang dapat menentukan dalam mengeksploitasi peluang bisnis. Dalam dunia industri kecil slondok para pemilik industri terlihat sengaja membentuk jaringan untuk memperluas hubungan dengan para pemilik industri lainnya.

\section{c. Norma (Norms)}

Norma sosial akan sangat berperan dalam mengontrol bentukbentuk perilaku yang tumbuh dalam masyarakat. Pengertian norma itu sendiri adalah sekumpulan aturan yang diharapkan dipatuhi dan diikuti oleh anggota masyarakat pada suatu etnis sosial tertentu. ${ }^{16}$

Norma merupakan suatu kesepakatan bersama yang akan berperan untuk mengontrol dan menjaga hubungan antara individu dengan individu lainnya dalam kehidupan sosial. Norma biasanya dibangun serta tumbuh dan dipertahankan untuk memperkuat masyarakat itu sendiri. Hal inilah yang membuat norma menjadi salah satu unsur dari modal sosial. Tetapi jika melihat norma yang tergabung dalam sebuah jaringan usaha, biasanya terbentuk secara spontan dan sifatnya informal. Konfigurasi norma sosial yang terbentuk dalam jaringan usaha industri kecil slondok di Desa Sumurarum terjadi secara spontan, juga akan menentukan apakah norma tersebut akan memperkuat kerekatan antar

\footnotetext{
${ }^{16}$ Jausairi Hasbullah. op.cit. hlm. 13.
}

para pelaku industri kecil slondok dan memberikan positif bagi para pelakunya dalam mendapatkan keuntungan.

\section{Pembahasan}

\section{Profil Industri Slondok}

Sentra industri kecil slondok di Desa Sumurarum dapat berkembang seperti sekarang ini karena melalui perjalanan panjang pasang surut dalam pemasaran hasil produksinya. Kegiatan memproduksi slondok pada penduduk setempat merupakan mata pencaharian utama, meskipun ada minoritas masyarakat yang tidak memproduksi slondok. Industri kecil slondok tersebut melibatkan beberapa komponen jaringan usaha yang saling terkait antara pengrajin, pembumbu, dan pemasok bahan baku.

$\begin{array}{ccr}\text { Industri } & \text { kecil } & \text { slondok } \\ \text { merupakan } & \text { industri } & \text { yang }\end{array}$
menghasilkan produk unggulan dalam kategori produksi makanan di kabupaten Magelang. Hasil produksi dari industri kecil slondok selalu mewakili kabupaten Magelang dalam Jakarta Fair sejak tahun 2006 sampai dengan 2009. Industri kecil slondok dikatakan sebagai produk unggulan Kabupaten Magelang karena hasil produksi dari industri kecil slondok mempunyai karakter sebagai berikut: 1) hasil industri kecil slondok tahan lama dan tidak berpengawet. 2) keuntungan yang dapat diraih dalam proses produksi dan pemasaran yang cukup tinggi. 3) dalam proses produksi industri 
kecil slondok mampu menyerap tenaga kerja lokal sehingga dapat meningkatkan kesejahteraan sosial dan ekonomi pada masyarakat Desa Sumurarum.

Bentuk pemasaran hasil produksi industri kecil slondok putihan dari pengrajin kepada pembumbu yang awalnya adalah bentuk transaksi dengan pembayaran dilakukan secara langsung dan bersamaan dengan pengambilan hasil produksinya. Dalam hal ini pembumbu tidak harus memesan slondok terlebih dahulu pada pengrajin karena pengrajin yang mencari pemasaran (pembumbu) untuk menjual hasil produksinya, sebagaimana tergambar dalam bagan dibawah ini:

Bagan 1.

Alur pemasaran hasil produksi dengan pembayaran secara langsung

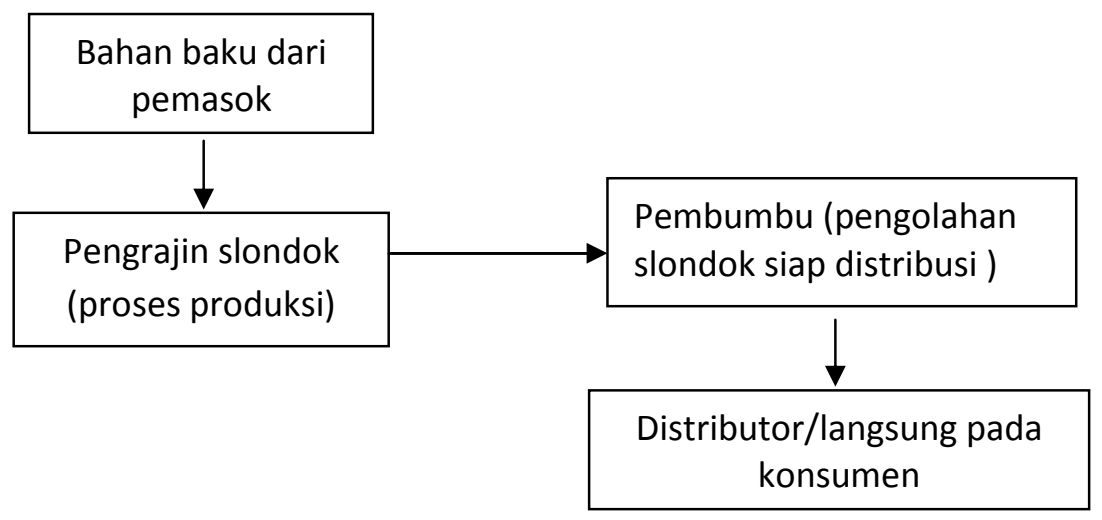

Sumber: data primer tahun 2010.

Berbeda dengan proses transaksi yang dilakukan sekarang, dimana penadah memberikan uang kepada pengrajin terlebih dahulu sebelum pengrajin membeli bahan baku dari pemasok (pembayaran dilakukan dimuka). Pembayaran dengan cara yang demikian dilakukan setelah industri kecil slondok mulai berkembang pesat dan permintaan pasar semakin meningkat yaitu sekitar tahun 1993 an sampai dengan tahun 2010. Maka dengan pembayaran di awal pembumbu dapat mengikat para pengrajin untuk tidak menjual hasil produksinya $\mathrm{k}$ epada pembumbu yang lain, selain itu pembumbu dapat mengontrol kualitas dari hasil produksi yang dihasilkan pengrajin. 
| Modal Sosial dalam Strategi Industri Kecil

Bagan 2.

Alur pemasaran hasil produksi dengan pembayaran di awal

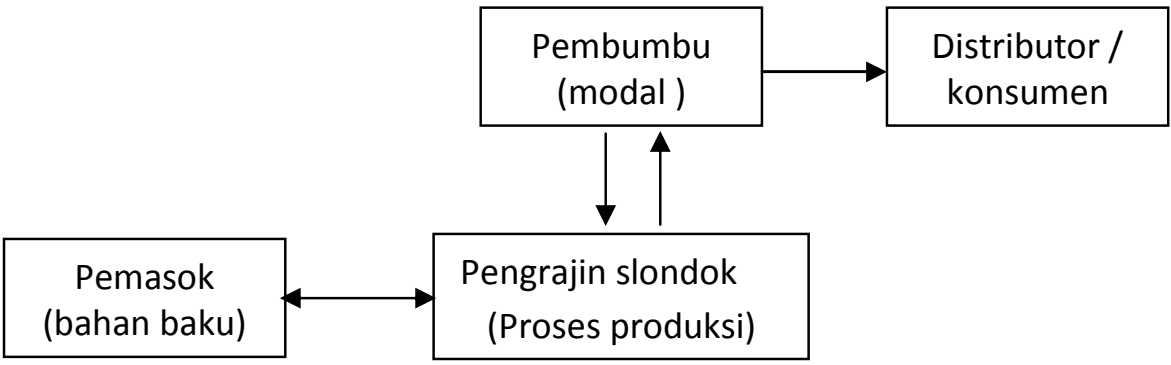

Sumber: data primer tahun 2010.

\section{Komponen Produksi}

Terdapat

beberapa

komponen produksi dalam industri kecil slondok yang saling terkait satu dengan yang lainnya dalam proses produksi. Selain itu juga terdapat beberapa istilah teknis sehubungan dengan penelitian ini yaitu pengrajin, penadah (pembumbu), buruh, dan pemasok. Masing-masing komponen dalam industri kecil slondok tersebut mempunyai aturan atau norma, kepercayaan dan jaringan sosial yang bisa digunakan sebagai strategi untuk bertahan dalam dinamika sosial pada masyarakat industri. Berikut ini akan dijelaskan masing-masing komponen produksi tersebut yaitu:

a. Pengrajin

Pengrajin adalah pemilik unit industri rumah tangga (industri kecil slondok) dengan kata lain komponen yang mengerjakan proses produksi slondok dari bahan baku segar hingga menjadi slondok tawar (putihan). Pengrajin mengerjakan proses produksinya tersebut di rumah sendiri. Dalam hal ini, rumah mempunyai fungsi ganda yaitu sebagai tempat tinggal sekaligus pabrik. Pengrajin mempunyai buruh serabutan yang siap membantu dalam proses pembuatan slondok dan mempunyai hubungan atau relasi usaha dengan penadah dalam pemasaran hasil produksinya. Pengrajin juga mempunyai hubungan atau relasi usaha dengan pemasok dalam pemesanan bahan baku dalam menjalankan industrinya tersebut.

b. Penadah (pembumbu) Penadah (pembumbu) merupakan komponen industri yang mempunyai peran besar dalam pemasaran slondok. Dalam sistem kerjanya penadah sebagai pengumpul slondok tawar (putihan) minimal dari tiga pengrajin yang kemudian diberi bumbu dulu sebelum dipasarkan. Penadah merupakan komponen penting dalam pendistribusian hasil industri karena peran modal sosial (kepercayaan, norma, dan jaringan sosial) dalam menjalankan perann ya sangat penting sebagai 
distributor. Karena hubungan yang terjalin didalamnya tidak hanya kepada pengrajin semata tapi kadang juga terhadap pemasok.

c. Buruh (serabutan)

Buruh adalah tenaga kerja atau penduduk sekitar yang tidak mempunyai industri kecil slondok dirumahnya dan pekerjaan yang dilakukannya adalah sebagai petani. Pekerjaan yang biasa dilakukan oleh buruh adalah oncek (pengupasan ketela pohon), memarut (proses menghaluskan ketela pohon), pengepresan (menghilangkan sari pati yang terkandung dalam ketela pohon), dan jewer (proses penghelaian slondok yang telah selesai digiling). Untuk proses jewer (penghelaian slondok) bisa dibawa pulang ke rumah, sehingga dalam satu waktu buruh bisa mengerjakan milik tiga sampai empat orang pengrajin. Kemudian untuk proses yang lainnya hanya bisa dikerjakan di tempat pengrajin.

Dalam proses pembuatan slondok dari proses segar sampai menjadi slondok siap distribusi dilakukan oleh tenaga laki-laki dan perempuan. Proses pengupasan ketela pohon, biasanya dilakukan oleh tenaga perempuan terdiri dari ibu-ibu dan remaja di desa tersebut yang kebetulan tidak sekolah atau sedang libur sekolah. Kemudian untuk pencucian, pemarutan, dan pengepresan dilakukan oleh laki - laki. Untuk proses yang lainnya dalam proses lanjutan dike rjakan sendiri oleh pemilik industri dan anggota keluarga kecuali pada proses penjeweran, biasanya dikerjakan oleh buruh.

Pemberian upah biasanya diberikan secara langsung untuk pengerjaan proses segar. Hitungan upah dalam proses ini menggunakan hitungan jam. Setengah hari kerja atau satu hari penuh dengan pemberian upah bersih, yaitu buruh sudah mendapatkan makan dan minum di tempat pengrajin. Perlu diketahui bahwa dalam pemberian upah antara pengupas, pemarut, dan pengepres tidak sama. Dimana upah diberikan setelah selesai dalam pengerjaan proses segar tersebut.

Pemberian upah dalam
proses lanjutan (penjeweran), diberikan secara akumulasi pada hari terakhir yaitu pada penjeweran terakhir dalam satu kali proses produksi. Dalam satu kali proses produksi penggilingan biasanya dilakukan dalam waktu empat hari, dan dalam satu kali penjeweran mereka dapat menyelesaikan enam kotak slondok yang telah digiling. Namun kadang pemberian upah jewer juga diberikan kapan buruh meminta upahnya dan tidak harus diberikan pada akhir penjeweran. 
| Modal Sosial dalam Strategi Industri Kecil

Tabel 1.

Upah Dalam Proses Pembuatan Slondok

\begin{tabular}{|c|c|c|}
\hline Jenis Pekerjaan & Perhitungan & Upah \\
\hline \multirow[t]{2}{*}{ Oncek } & setengah hari & Rp. 6.000,- \\
\hline & sehari penuh & Rp. 10.000,- \\
\hline Memarut & $\begin{array}{ll}\text { satu } & \text { kali } \\
\text { proses } & \end{array}$ & Rp. 20.000,- \\
\hline Mencuci ketela & $\begin{array}{l}\text { satu } \\
\text { proses }\end{array}$ & Rp. 20.000,- \\
\hline Pengepresan & $\begin{array}{l}\text { satu } \\
\text { proses }\end{array}$ & Rp. 20.000,- \\
\hline Jewer & satu kotak & Rp. $\quad 450,-$ \\
\hline
\end{tabular}

Sumber: Data primer yang telah diolah.

Upah jewer diterima oleh para buruh berdasarkan akumulasi penjeweran slondok, misalkan setiap sore mereka jewer sepuluh kotak (enam kotak adalah batasan minimal jewer) sampai pada hari ke empat maka gaji yang akan diterimanya adalah Rp.450, - dikali sepuluh kemudian dikalikan empat kali. Itu untuk penjeweran pada satu pemilik industri, biasanya mereka jewer pada tiga sampai empat pemilik industri.

\section{d. Pemasok}

Pemasok dalam industri kecil slondok ini merupakan pemasok bahan baku (ketela pohon). Dimana dalam berjalannya industri pemasok mempunyai andil yang sangat besar, karena tanpa adanya pemasok pengrajin tidak akan bisa mendapatkan bahan baku untuk menjalankan proses produksi. Pemasok mempunyai jaringan usaha atau relasi usaha yang sangat kuat dengan para pengrajin, dimana dalam jaringan yang terjalin tersebut tidak bisa terlepas dari kepercayaan dan juga aturan-aturan yang menjalin hubungan tersebut.

\section{Strategi dalam pengembangan industri slondok}

a. Peran kepercayaan dalam perolehan modal

Kepercayaan adalah keadaan yang dapat dipercaya, sering diibaratkan dengan suatu minyak pelumas yang meminyaki roda transaksi ekonomi dan sosial yang tanpanya sangat mahal dan makan banyak waktu. Kepercayaan adalah efek samping yang sangat penting dari norma-norma sosial yang kooperatif yang memunculkan social capital. ${ }^{17}$

Pengharapan yang diinginkan pada masyarakat dalam sentra industri kecil slondok adalah kejujuran dan keseriusan dalam penggarapan proses produksi slondok, sebagai bentuk tanggung jawab atas kepercayaan yang telah

\footnotetext{
17 Francis Fukuyama, The Grest Discruption (Hakikat Manusia dan Rekonstruksi Tatanan Sosial). Jakarta -Qolam: 2007. Hlm.72.
} 
terbentuk dalam relasi antar komponen pada masyarakat tersebut. Dalam beberapa penuturan informan yang berperan sebagai pembumbu terlihat bahwa kepercayaan memiliki kekuatan sangat vital dalam berkembang industri kecil slondok pada masyarakat Desa Sumurarum, yaitu dengan adanya rasa saling percaya antar komponen industri yang memudahkan bagi aktor industri (pengrajin, pembumbu, pemasok bahan baku dan para buruh) dalam berbagai akses. Misalnya, dalam relasi pengrajin dengan pembumbu yaitu dengan pengrajin meminta pembayaran diawal dalam transaksi slondok putihan, dapat menggambarkan bagaimana kepercayaan berperan sangat vital dalam perolehan modal pada industri kecil slondok.

Pembayaran sondok diawal juga mempunyai keuntungan tersendiri bagi para pembumbu dengan kata lain pembayaran slondok tersebut sebagai pengikat dan untuk memperkuat rasa percaya pembumbu kepada pengrajin yakni dengan pembayaran diawal maka pengrajin tidak menjual hasil produksinya pada pembumbu lain. Hubungan yang demikian dinamakan dengan kemitraan. Pembayaran di awal selain untuk meningkatkan rasa percaya terhadap pengrajin juga merupakan strategi bagi pembumbu untuk tetap berkembang untuk memenuhi permintaan pasar. Karena dengan adanya pembayaran di awal maka pengrajin tidak akan menjual hasil produksinya pada pembumbu lain. b. Peran kepercayaan dalam akses bahan baku

Bahan baku merupakan sumber utama dalam proses produksi pada industri kecil slondok, tanpa adanya bahan baku maka proses produksi akan terhenti dan industri tidak akan berkembang. Awalnya transaksi yang dilakukan antara pengrajin dan pemasok bahan baku mensyaratkan pembayaran dilakukan bersamaan dengan datangnya bahan baku yang telah dipesan. Bila pengrajin terpaksa tidak bisa membayar ketela pada saat ketela datang maka pihak pemasok mempunyai kebijakan rowek (pengrajin menggarap slondok untuk pemasok dan perhitungan pembayaran dilakukan di akhir setelah slondok sudah jadi).

Namun sekarang kebijakan rowek jarang sekali dilakukan oleh pemasok, dan jika rowek terus dilaksanakan maka dari pihak pemasok pun juga harus mencari pembumbu yang mau membeli slondoknya dan itu berarti pemasok harus kerja dua kali. Selain itu dalam pemasaran slondok putihan biasanya pembumbu memberi modal terlebih dahulu pada para pengrajin maka rowek pun juga jarang sekali dilakukan oleh pemasok.

c. Peran kepercayaan dalam akses tenaga kerja

Selain modal dan bahan baku

dalam proses produksi pada industri slondok juga memerlukan tenaga kerja. Untuk membantu mengerjakan sebagian pekerjaan dalam proses segar pada tahapan produksi slondok, peran buruh di 
sini adalah untuk oncek, memarut, dan pengepresan. Dalam tahapan proses segar ini biasanya pengrajin mempercayakan pada satu orang yang nantinya akan mencari teman sesama buruh untuk mengerjakan proses segar tersebut.

Dalam pengerjaan proses segar kepercayaan juga berperan sangat penting untuk bisa menyelesaikan rangkaian proses produksi pada tahapan proses segar. Di sini pengrajin juga ikut membantu dalam pemarutan dan menyiapkan makanan serta jajanan bagi para buruh. Kemudian untuk proses lanjutan buruh dibutuhkan untuk jewer (penghelaian) di mana dalam hal ini buruh yang dibutuhkan adalah separuh dari buruh pada tahapan proses segar, dan biasanya pengrajin tinggal memanggil tetangga terdekat yang biasanya juga buruh serabutan.

\section{Modal Sosial dalam Strategi Industri Slondok \\ Dalam rangka}

mempertahankan kelangsungan kehidupannya manusia selalu membutuhkan pertolongan serta mengadakan kerjasama dengan manusia lain. Ini berarti bahwa manusia selalu mencari kumpulan atau pergaulan dengan sesamanya agar kebutuhan hidupnya terpenuhi, mereka melakukan berbagai aktivitas ekonomi maupun sosial dilingkungan tempat tinggal mereka tersebut.

Berkaitan dengan modal sosial yang terbentuk dalam strategi industri kecil slondok di Desa
Sumurarum tidak terlepas dari tujuan individu untuk dapat mencari dan berhubungan dengan individu lainnya. Semua itu tentunya demi kelangsungan dan kesejahteraan hidup yang lebih baik. Dimana industri kecil slondok membutuhkan mata rantai yang saling mendukung untuk berkembang. Menurut Bourdieu dan Wacquant modal sosial merupakan sejumlah sumbersumber daya, aktual atau virtual (tersirat) yang berkembang pada seorang individu atau sekelompok indivi du karena kemampuan untuk memiliki suatu jaringan yang dapat bertahan lama dalm hubunganhubungan yang lebih kurang telah diinstitusikan berdasarkan pengetahuan dan pengenalan timbal balik. ${ }^{18}$ Dalam industri kecil slondok sumber-sumber aktual yang berkembang dalam sekelompok individu aktor industri adalah sebagai berikut:

a. Kepercayaan mendorong komponen industri untuk bertindak.

Bertindak yang dimaksudkan dalam hal ini seperti halnya penadah yang mau memberikan moda 1 di awal untuk membeli bahan baku dalam proses produksi dulu awalnya transaksi yang dilakukan adalah pembayaran secara langsung yaitu ada slondok ada uang. Namun dengan adanya interaksi yang terjalin dan tingkat kepercayaan yang semakin tinggi

\footnotetext{
${ }^{18}$ John field. Modal Sosial, Medan: Media Perintis, 2005, hlm. 20 -21
} 
maka penadah dengan mudah mau memberikan uang di awal. Begitu juga dalam transaksi yang terbentuk antara pemasok dengan pengrajin. Pada sekarang ini kalau pengrajin bisa dengan mudah meminta bahan baku terlebih dahulu pada pemasok baru setelah slondok terjual ketela dibayar.

Dengan adanya tingkat kepercayaan yang tinggi maka pemasok bisa lebih berani dalam memberikan bahan baku dengan sistem pembayaran diakhir. Penadah juga berani dalam membayar slondok di awal yaitu sebelum slondok jadi sebagai modal membeli bahan baku.

Kepercayaan juga mempunyai peran yang sama dalam transaksi perdagangan yang dilakukan oleh penadah (pembumbu) pada agen ataupun pabrik, yaitu dengan adanya kepercayaan para penadah berani mengirim slondok terlebih dahulu melalui sopir truk dan pembayaran yang dilakukan adalah melalui transfer. Awalnya penadah sendiri yang mengirim slondok pada agen dan pabrik -pabrik. Dengan adanya tingkat kepercayaan yang semakin tinggi dalam interaksi antara keduanya maka dilandasi dengan rasa saling percaya penadah pun berani mengambil tindakan seperti di atas.

b. Kepercayaan membantu merekatkan hubungan setiap komponen industri dalam interaksinya

Kepercayaan dalam

pengemban gan industri kecil slondok dapat merekatkan hubungan setiap komponen industri karena dalam terbentuknya sebuah kepercayaan memerlukan waktu yang lama (seiring dengan adanya interaksi antar komponen) dalam industri kecil slondok tersebut. Seperti yang terlihat dalam pendekatan sosiologi ekonomi yaitu dengan pendekatan "keterlekatan" yang mempunyai pandangan bahwa kepercayaan tidak muncul dengan seketika akan tetapi muncul dari berbagai proses hubungan antar individu yang sudah lama terlibat dalam perilaku ekonomi (jaringan usaha) secara bersamasama. Maka dengan adanya rasa saling percaya antarindividu (pelaku industri) akan menambah semakin eratnya ikatan atau relasi bisnis yang terjalin didalamnya.

c. Kepercayaan menjadi aset penting dalam menumbuhkan modal sosial.

Kepercayaan menjadi aset penting dalam modal sosial karena tanpa adanya kepercayaan sebuah jaringan tidak akan pernah terbentuk, meskipun terbentuk akan tetapi jaringan yang ada akan bersifat lemah. Karena kepercayaan di sini menjadi dasar terbentuk nya jaringan, yaitu semakin tinggi tingkat kepercayaan dalam sebuah interaksi maka akan semakin kuat pula jaringan yang mengikatnya. Setelah adanya kepercayaan dan jaringan sosial maka suatu kebiasaan baik yang terjadi didalamnya akan melembaga dan menjadi norma yang mendasari hubungan atau interaksi antar komponen industri tersebut. 
| Modal Sosial dalam Strategi Industri Kecil

\section{Jaringan}

Jaringan sosial dalam kegiatan ekonomi termasuk dalam industri kecil slondok memiliki peran yang cukup penting karena tanpa adanya jaringan usaha tentunya industri tid ak akan bisa berkembang.

a. Membantu mengakses informasi

Jaringan dapat membantu mengakses informasi mengenai segala hal yang berkaitan dengan industri kecil slondok. Misalnya kesediaan dan harga bahan baku, harga jual putihan, dan juga mengenai inovasi-inovasi dalam pembuatan slondok. Selain hal tersebut jaringan juga bisa memberikan informasi mengenai daerah pemasaran bagi penadah (pembumbu).

b. Membantu mendapatkan rekan bisnis.

Jaringan bisa membantu mendapatkan rekan bisnis, yaitu dengan adanya jaringan sosial orang bisa lebih mudah mendapatkan rekan bisnis, misalnya penadah jadi lebih mudah dalam mengakses pengrajin, pengrajin juga lebih mudah untuk mengakses bahan baku (dengan adanya jaringan usaha dengan pemasok bahan baku) sekaligus tenaga kerja. Selain hal tersebut jaringan juga sangat membantu dalam proses pemasaran bagi penadah.

c. Membantu mengakses sumber daya

Dalam industri kecil slondok jaringan bisa membantu mengakses sumber daya baik itu sumber daya manusia (tenaga kerja), atau sumber daya alam (bahan baku), ataupun sumber financial (keuangan) yang biasanya dapat di akses dari para penadah (pembumbu). Dalam kaitannya dengan pengaksesan bahan baku, jaringan sangat membantu pemasok dalam mendapatkan bahan baku dari petani langsung. Karena dengan adanya simpul-simpul penghubung baik yang bersifat lemah atau kuat akan mempermudah individu mengakses apa yang dia perlukan.

\section{Norma (Norms)}

Norma yang berlaku dalam industri merupakan kesepakatan bersama yang berfungsi mengontrol dan menjaga hubungan antar komponen industri yang satu dengan komponen industri yang lain. Dalam industri kecil slondok ini norma memiliki beberapa fungsi diantaranya:

a. Meminimalkan kemungkinan penyimpangan dalam produksi slondok

Penyimpangan yang dimaksudkan disini adalah penyimpangan yang dilakukan oleh komponen industri tertentu yang dapat merugikan komponen industri yang lain seperti halnya pemakaian bahan pemutih terlalu banyak. Ketela yang di kirim (sebagai bahan baku) sengaja diberi bahan baku yang jelek dan lain sebagainya. Dengan adanya norma yang muncul di dalam interaksi antar komponen disini maka penyimpangan-penyimpangan tersebut tidak ada. Karena misalkan 
terjadi penyimpangan dengan adanya norma maka akan terdapat sanksi didalamnya, jika dikontekskan dalam contoh penyimpangan di atas maka sanksi yang akan diterima adalah dengan cara menurunkan harga putihan dan pengembalian bahan baku pada pemasok.

b. Membantu mengatur dan menstabilkan harga dalam berbagai transaksi pada industri slondok

Norma merupakan suatu kesepakatan bersama yang berperan untuk mengontrol dan menjaga hubungan antar individu dalam lingkungan sosial. Dalam industri kecil slondok norma berperan sebagai pengatur dan menstabilkan harga baik dalam transaksi pengrajin dengan penadah. Hal tersebut dimaksudkan agar pembumbu tidak semena-mena dalam menurunkan harga ketika slondok tidak bagus. Dan dalam transaksi jasa terhadap buruh norma berperan sebagai pengatur dengan tujuan ketika keadaan perekonomian sedang kalut (semua harga naik) maka pengrajin bisa memberi kebijakan kenaikan upah atas pekerjaan yang dikerjakan oleh buruh.

c. Membantu tiap pelaku industri mendapatkan kepercayaan dan jaringan

Dalam sebuah jaringan usaha norma yang terbentuk bersifat spontan, dan hal tersebut merupakan kebiasaan -kebiasaan yang lambat laun melembaga menjadi sebuah aturan baku yang tercipta dalam jaringan usaha tersebut.
Ketiga komponen modal sosial (kepercayaan, jaringan dan norma), mempunyai peran yang saling terkait satu sama lain dalam strategi industri kecil slondok. Namun dalam keterkaitan tersebut terdapat satu komponen modal sosial yang mendominasi pada satu strategi, dalam proses produksi pada industri kecil slondok komponen modal sosial yang berperan paling dominan adalah kepercayaan. Dimana dengan adanya tingkat kepercayaan yang tinggi dan didasari dengan adanya jaringan yang kuat antar komponen industri maka dalam proses produksinya pengrajin dapat dengan mudah mengakses modal, bahan baku, dan tenaga kerja.

\section{Kesimpulan}

Berdasarkan hasil penelitian dan analisis data mengenai modal sosial dalam strategi industri kecil, yang mengkaji tentang industri kecil slondok di Desa Sumurarum, Kecamatan Grabag, Kabupaten Magelang dapat diambil beberapa kesimpulan sebagai berikut:

a. Industri di Desa Sumurarum merupakan industri makanan yang berkembang mulai dari satu unit industri. Dan dengan berbagai upaya dalam pengembangannya yang tidak terlepas dari adanya modal sosial sebagai strategi dalam pengembanganya kini bisa menjadi sentra industri kecil di Kabupaten Magelang.

b. Kepercayaan mempunyai peran penting dalam proses produksi pada industri kecil 
slondok. Peran kepercayaan disini adala $\mathrm{h}$ dalam perolehan modal, perolehan bahan baku serta tenaga kerja yang pengrajin butuhkan khususnya dalam proses segar.

c. Norma dalam industri kecil slondok adalah sebuah kesepakatan bersama yang berfungsi menjaga hubungan antar komponen industri yang satu dengan yang lain. Peran norma dalam industri kecil slondok adalah sebagai penstabilisasian harga dalam berbagai trtansaksi yang terbentuk dalam industri kecil slondok, baik dalam penentuan harga bahan baku maupun harga pada pemasaran hasil produksi dalam industri kecil slondok (slondok putihan) yang ditentukan juga oleh jauh dekatnya tempat distributor atau pemesan.

d. Jaringan sosial mempunyai peran penting dalam perkembangan industri kecil slondok, yaitu dalam hal pemasaran slondok siap distribusi. Jaringan pemasaran disini sangat berperan untuk memudahkan mobilitas dalam membentuk sebuah relasi bisnis (pemasaran slondok) dan perolehan informasi baru mengenai apa yang sedang konsumen butuhkan.

\section{Daftar Pustaka}

Agus Dwiyanto, Manusia dan Pembangunan, Jakarta: Rajawali, 1996.

Damsar, Sosiologi Ekonomi. Jakarta: Raja Grafindo Persada, 1997, hlm. 42.

Depdiknas, Kamus Besar Bahasa Indonesia, Jakarta: Balai Pustaka, 2005.

Hendrawan Supratikno, Perkembangan Industri Kecil di Indonesia, majalah PRISMA, No 9, 1994.

Francis Fukuyama, The Great Disruption (Hakikat Manusia dan Rekonstruksi Tatanan Sosial). Jakarta: Qalam, 2007, hlm. 22.

Irsan Azhary Saleh, Industri Kecil (Sebuah Tinjauan dan Perbandingan). 1986.

Jausairi Hasbullah, Social Capital (Menuju Keunggulan Budaya Manusia Indonesia), Jakarta: MR-United Pres, 2006.

John Field, Modal Sosial. Medan: Bina Media Perintis, 2005.

Mubyarto, Politik Pertanian dan Pembangunan Desa. Jakarta: Sinar Harapan. 1983. 
| Eni Fitriawati

DIMENSIA, Volume 4, No. 1, Maret 2010 | 40 